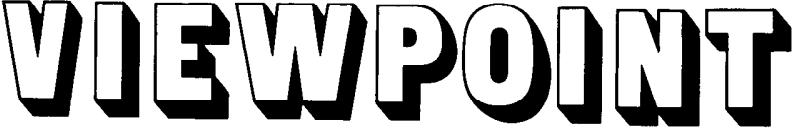

\section{A Student's Views on the Future of the Society for Range Management}

\section{RICHARD F. MILLER}

As a student I am concerned with the future role that the Society for Range Management will play. I believe that the success of range management very much depends upon the strength of this professional organization. Working as individuals we have little chance of making much progress. Working as a unified group through the Society for Range Management we have the opportunity to manage rangeland resources on an ecological basis rather than a political one. The following four points I believe to be essential in managing range resources.

The first of these is adapting to change. As a society of professionals, we must become sensitive to demands and needs placed upon rangeland resources. These needs and demands are constantly changing with time. As the needs of society shift, the demands on range resources shift. To be effective we must adapt ourselves to these constant changes. We should try to project the future by looking at past and present trends. But even then we can get only a vague idea of things to come.

The second point is the image of a

The author is a graduate research assistant, Rangeland Resources Program, Oregon State University, Corvallis. rangeman. I believe that our present image limits our full potential as rangeland resource ecologists. A large portion of the general public isn't really sure what a rangeman is. Many special interest groups look at us as livestock managers. Too often we simply manage range resources to suit the needs for livestock production. This creates an image that not only limits our acceptance by other professionals, but even more limits our influence as professionals to the public. I would like to see us project the image of Rangeland Resource Ecologists; professionals who can look at the entire picture and fit the land potentials, on a sound ecological basis, to the needs of the public.

The point is that we must become more influential in the public eye. A large portion of today's management is nothing but legislative fiat. Decisions are based on emotions that obscure the facts. We must base our decisions and statements on sound ecological facts. We must use the correct timing and place for introducing ideas and objectives if they are to have an impact. And, as professionals, we must avoid emotionalism, a tool that is tough to control.

Thirdly, we should become effective in integrating our profession with other professional fields. Sound environmental management requires multiple inputs from such areas as range management, geology, forest management, wildlife management, political science, social science, and a long list of others. Maybe I'm a little biased, but I think the range ecologist certainly has the qualities, with his broad background, to lead such a group.

The last and final point: What are our, the Society for Range Management, goals? I'm sure most of us could state goals that are so broad that we could all agree on them. For example, "To improve the environmental quality and at the same time harvest optimum levels of multiple products on the rangelands." Improvement of environmental quality sounds pretty good, but what is environmental quality? Does it mean clean air or unpolluted waters? What is environmental quality to a dune buggy fanatic may differ considerably from the environmental quality expected by someone who enjoys the quiet and beauty of an unspoiled desert. To many people, environmental quality is just knowing something is there, like the wild horse, even though they may never see it. People get a certain amount of inner satisfaction just by knowing this entity in the environment exists.

For the Society for Range Management to be effective in manipulating sound ecological management, we must work together. We must agree upon a set of goals that we have pinned down and defined. It is extremely difficult to lay down a set of objectives when we have no definable goals. 